\title{
A Meta-Analysis of the Impact of Monensin in Lactating Dairy Cattle. Part 3. Health and Reproduction
}

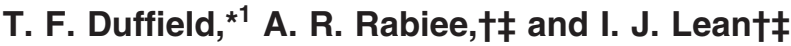 \\ *Department of Population Medicine, University of Guelph, Guelph, Ontario, Canada N1G 2W1 \\ †Strategic Bovine Services, PO Box 660, Camden, New South Wales, Australia 2570 \\ łUniversity of Sydney, Camden, New South Wales, Australia
}

\section{ABSTRACT}

A meta-analysis of the impact of monensin on health and reproductive outcomes in dairy cattle was conducted. A total of 16 papers were identified with sufficient data and quality to evaluate health and reproductive outcomes for monensin. The available trials provided approximately 9,500 cows with sufficient data for analysis. This provided good statistical power to examine the effects of monensin on health and reproduction. Over all the trials analyzed, monensin decreased the risk of ketosis [relative risk $(R R)=0.75$ ], displaced abomasums $(R R=0.75)$, and mastitis $(R R=$ 0.91). No significant effects of monensin were found for milk fever, lameness, dystocia, retained placenta, or metritis. Monensin had no effect on first-service conception risk $(\mathrm{RR}=0.97)$ or days to pregnancy (hazard ratio $=0.93$ ). However, the impact of monensin on dystocia, retained placenta, and metritis was heterogeneous for all 3 outcome measures and random effect models were utilized. Causes of the heterogeneity were explored with meta-regression. Days of treatment with monensin before calving increased the risk of dystocia. Delivery method of monensin influenced the incidence of retained placenta and metritis, with risk being lower with controlled release capsule treatment compared with delivery in either topdress or in a total mixed ration. Days of treatment before calving also influenced retained placenta with an increase in risk with more days treated before calving. Improvements in ketosis, displaced abomasums, and mastitis with monensin were achieved. Exposure to prolonged treatment in the dry period with monensin may increase the risk of dystocia and retained placenta.

Key words: monensin, dairy cattle, meta-analysis, health and reproduction

Received October 23, 2007.

Accepted February 27, 2008.

${ }^{1}$ Corresponding author: tduffiel@uoguelph.ca

\section{INTRODUCTION}

Monensin is widely used in dairy herds including those in the United States, Canada, Mexico and South America, Australia, New Zealand, and South Africa. Although the effects of monensin on rumen fermentation are relatively well described, there is much less information available on the impacts of this treatment on health and reproduction. Monensin treatment selectively inhibits gram-positive bacteria in the rumen though an anti-porter action (Russell and Strobel, 1989). Consequently, volatile fatty acid production is altered, and increased production of propionate and decreased acetate and butyrate production is commonly reported. These changes in bacterial populations increase the efficiency of energy metabolism, improve nitrogen metabolism, and reduce the risk of bloat and lactic acidosis (Bergen and Bates, 1984; Lowe et al., 1991). Improved energy and protein metabolism, and a reduced risk of rumen acidosis should result in measurable health benefits for cattle, particularly in early lactation when the incidence of metabolic disease is greatest.

The hypothesis that monensin can improve health and fertility has been investigated in quite large randomized controlled clinical studies (Lean et al., 1994a; Beckett et al., 1998; Heuer et al., 2001; Duffield et al., 2002). Some studies reported a lower risk of abomasal displacement (Duffield et al., 2002) and others a reduced risk of mastitis (Heuer et al., 2001). Other studies did not identify significant health benefits (Beckett et al., 1998). Despite several large studies being conducted and confirmation of substantial, positive effects of monensin on energy metabolism (Duffield et al., 2008a), no reproductive benefits of monensin have been reported (Lean et al., 1994a; Hayes et al., 1996; Duffield et al., 1999; Heuer et al., 2001); a previous meta-analysis of the early large studies indicated that there was little prospect of a significant effect of monensin on reproductive performance (Lean and Wade, 1997). Given the large body of literature on monensin in dairy cattle and recent approvals in the United States and Canada for 
use in lactating dairy cattle, it was concluded that an investigation of monensin using meta-analytic methods would be helpful in describing monensin's impact on cow health and reproduction, and possibly in explaining differences in response. The objective of this project was to conduct a series of meta-analyses on the effects of monensin on dairy cow metabolism, health, production responses, and reproductive performance. The first 2 papers published in this series of papers examined the impact of monensin on metabolic indicators in lactating dairy cattle (Duffield et al., 2008a) and the effect of monensin on production parameters in lactating dairy cattle (Duffield et al., 2008b). The purpose of this study was to describe the health and reproductive effects of monensin in lactating dairy cattle.

\section{MATERIALS AND METHODS}

Methods of the literature search and screening process have been described previously (Duffield et al., 2008a). Briefly, an extensive literature search of scientific electronic search engines and acquired trial reports was conducted. Following rigorous screening for appropriate subject matter, quality of trial design, and adequate statistical reporting, data were extracted for meta-analysis. Additional data were sought from authors of papers and these raw data were used for the survival analyses reported in this paper.

Sixteen papers were available to evaluate the impact of monensin on health and reproductive outcomes in lactating dairy cattle (Table 1 ). In addition, disease data known to be collected but not published in 2 of these studies (Zahra et al., 2006; Petersson-Wolfe et al., 2007) were solicited for use in the meta-analysis. A template for data extraction was drafted, which included number affected and unaffected for each disease in treatment and control animals. Other factors that might influence outcomes were also included in the data extraction process including days in milk at treatment start, stage of lactation for the data, treatment dose, duration of treatment, method of delivery of monensin [in-feed (TMR), topdress or controlled release capsule (CRC)], breed, and diet type (pasture, component, or TMR). There was only one study in which treatment began during the precalving period and then ended at calving (Vallimont et al., 2001); in all other studies treatment continued into the lactating period.

Health outcomes examined included dystocia, retained placenta (RP), milk fever (MF), metritis, endometritis, ketosis, abomasal displacement (DA), mastitis, lameness, and culling. In most papers these diseases were recorded as occurring or not occurring (dichotomous). Disease definitions were not standardized across studies but the same disease definitions were used within study between treatments. In one study (Green and Wilkinson, 2004) dystocia was recorded as both veterinary assisted and observed on farm with several categories including unassisted, easy, moderate, difficult, and very difficult. In this case, dystocia was defined to be an animal recorded (observed on farm) with either a difficult or very difficult calving. Dystocia in other studies was recorded if veterinary assistance occurred (Duffield et al., 1999, 2002), any assistance was required (Heuer et al., 2001) or if 2 or more people were required for calf extraction (Melendez et al., 2006a). In one study no definition for dystocia was provided (Beckett et al., 1998). For most studies RP was defined if the placenta was present at or more than $24 \mathrm{~h}$ postcalving. However, this disease was not defined for 3 studies (Beckett et al., 1998; Heuer et al., 2001; Vallimont et al., 2001). Occurrence of DA included both right and left displacements for all studies, although the vast majority of displacements are left (Whitlock, 1969). Definitions of milk fever, metritis, ketosis, and clinical mastitis were not provided for several studies (Wilson et al., 1992; Heuer et al., 2001; Vallimont et al., 2001; Green and Wilkinson, 2004). Definitions for these diseases were similar for the other studies and to those recommended by Kelton et al. (1998). First-service conception risk (FSCR) was collected and analyzed in the same manner as the health outcomes. For the pooled survival analysis of time to pregnancy, data on treatment and pregnancy were pooled from 6 trials.

All meta-analyses were conducted on the extracted health outcomes using Stata (Intercooled Stata, V. 9.0, Stata Corp., College Station, TX). Guidelines for conducting appropriate meta-analysis were largely based on meta-analytic techniques described by Dohoo et al. (2003). A Mantel-Haenszel fixed effect model was first conducted for each health outcome to estimate the risk ratio (RR), 95\% confidence intervals, and statistical significance of RR. Heterogeneity of the estimated RR was assessed with the Cochran's Q statistic chi square test (Egger et al., 2001). If there was evidence of heterogeneity, then a random effect model (inverse variance) was used. Degree of heterogeneity was assessed by use of the $I^{2}$ statistic (Higgins et al., 2003). Sources of heterogeneity of response were explored using meta-regression, which uses the individual log of $R R$ for each trial as the outcome and the associated log of the standard error as the measure of variance. Meta-regression was conducted by first screening individual variables such as dose, days in milk at treatment start, and delivery method in a univariate analysis with a liberal $P$-value of $P=0.20$ used to declare significance for further multivariate regression. All variables meeting the first screening criteria were entered into a backward stepwise regression method until all remaining variables 
Table 1. Summary of studies used for meta-analysis of health and reproductive effects of monensin in lactating dairy cow

\begin{tabular}{|c|c|c|c|c|c|c|c|c|}
\hline Study & $\begin{array}{c}\text { Trials, } \\
\mathrm{n}\end{array}$ & $\begin{array}{l}\text { Dose of } \\
\text { monensin, } \\
\mathrm{mg} / \mathrm{d}\end{array}$ & $\begin{array}{l}\text { Form of } \\
\text { monensin }\end{array}$ & $\begin{array}{l}\text { Total } \\
\text { cows, } \\
\mathrm{n}\end{array}$ & $\begin{array}{l}\text { Trial } \\
\text { sites, } \\
\mathrm{n}\end{array}$ & $\begin{array}{l}\text { Type } \\
\text { of diet }\end{array}$ & $\begin{array}{l}\text { DIM at } \\
\text { treatment } \\
\text { start }\end{array}$ & Measured outcomes ${ }^{1}$ \\
\hline Wilson et al. (1992) & 2 & 320 & $\mathrm{CRC}^{2}$ & 120 & 1 & Pasture & $-21,+2$ & MF, ketosis, mastitis, FSCR \\
\hline Lean et al. (1994b) & 1 & 320 & CRC & 908 & 6 & $\begin{array}{l}\text { Pasture, } \\
\text { TMR }\end{array}$ & 4 & FSCR, days to pregnancy \\
\hline Hayes et al. (1996) & 1 & 320 & CRC & 661 & 3 & Pasture & 60 & FSCR \\
\hline Beckett et al. (1998) & 1 & 320 & CRC & 1,109 & 12 & Pasture & -40 & $\begin{array}{l}\mathrm{RP} \text {, endometritis, MF, ketosis, dystocia, } \\
\text { mastitis, lameness, metritis, FSCR, } \\
\text { days to pregnancy }\end{array}$ \\
\hline Duffield et al. (1999) & 1 & 320 & CRC & 1,010 & 25 & $\begin{array}{l}\text { Component, } \\
\text { TMR }\end{array}$ & -21 & $\begin{array}{l}\text { RP, endometritis, MF, ketosis, DA, } \\
\text { dystocia, mastitis, lameness, metritis, } \\
\text { FSCR, days to pregnancy, culling }\end{array}$ \\
\hline Heuer et al. (2001) & 2 & 300 & Topdress & 894 & 12 & TMR & $-21,+35$ & $\begin{array}{l}\mathrm{RP} \text {, endometritis, MF, ketosis, dystocia, } \\
\text { mastitis, lameness, FSCR, days to } \\
\text { pregnancy, culling }\end{array}$ \\
\hline $\begin{array}{l}\text { Vallimont et al. } \\
(2001)\end{array}$ & 2 & 300 & Topdress & 57 & 1 & TMR & -28 & RP, MF, DA, ketosis, mastitis \\
\hline Tallam et al. (2003) & 1 & 450 & TMR & 37 & 1 & TMR & -21 & FSCR \\
\hline $\begin{array}{l}\text { Green and Wilkinson } \\
(2004)\end{array}$ & 6 & $\begin{array}{l}160,311 \\
451,178 \\
351,505\end{array}$ & TMR & 1,031 & 9 & TMR & -21 & $\begin{array}{l}\text { RP, endometritis, MF, ketosis, DA, } \\
\text { dystocia, mastitis, lameness, metritis, } \\
\text { FSCR, days to pregnancy, culling }\end{array}$ \\
\hline Melendez et al. (2006a) & 1 & 320 & CRC & 580 & 1 & TMR & -60 & Dystocia, RP, metritis, DA, culling, FSCR \\
\hline Gallardo et al. (2005) & 1 & 320 & $\mathrm{CRC}$ & 58 & 1 & Pasture & -30 & FSCR \\
\hline Zahra et al. (2006) & 1 & 320 & $\mathrm{CRC}$ & 182 & 1 & TMR & -21 & $\begin{array}{l}\text { DA, ketosis, RP, MF, metritis, mastitis, } \\
\text { FSCR }\end{array}$ \\
\hline Melendez et al. (2006b) & 4 & 320 & CRC & 1,671 & 1 & TMR & -25 & RP, FSCR \\
\hline $\begin{array}{l}\text { Petersson-Wolfe et al. } \\
(2007)\end{array}$ & 2 & 254,320 & $\begin{array}{l}\text { TMR, } \\
\text { CRC }\end{array}$ & 136 & 1 & TMR & -21 & $\begin{array}{l}\mathrm{RP}, \mathrm{MF} \text {, ketosis, DA, dystocia, mastitis, } \\
\text { lameness, metritis }\end{array}$ \\
\hline
\end{tabular}

${ }^{1} \mathrm{MF}=$ milk fever; FSCR = first-service conception risk; $\mathrm{RP}=$ retained placenta DA = displaced abomasum.

${ }^{2} \mathrm{CRC}=$ controlled release capsule.

were significant at $P<0.05$. All significant variables were screened for impacts of outliers. Forest plots were used to visually display the RR and weights given to the studies. Publication bias was investigated both graphically with funnel plots and statistically using both Begg's (Begg and Manumdar, 1994) and Egger's (Egger et al., 1997) tests. Finally, the influence of individual studies was assessed with the use of an influence analysis to determine the impact of removing individual studies on the RR estimate (Dohoo et al., 2003).

The effect of monensin on time to pregnancy was assessed with survival analysis. Survival analysis was performed using proportional hazards regression (PHREG) procedures in SAS V. 9.10 (SAS Institute Inc., Cary, NC). The assumption of proportional hazards was verified by plotting the $-\log [\log$ (survival function) $]$ for each treatment against the natural logarithm of time to pregnancy and confirming that the curves were parallel by visual inspection (Collett, 1994). It was assumed that correlation exists among cows within a farm through feeding, housing and environment, genetics, management policy or programs, which represent un- measured sources of heterogeneity of effects. To attempt to account for this correlation, the effect of within-farm clustering was adjusted for in the survival analyses using the PHLEV macro to adjust standard errors and $P$-values from the Cox proportional hazards models (Bergstralh et al., 1993).

\section{RESULTS}

A summary of the studies used for the various health and FSCR analyses is presented in Table 1 . There were 28 trials in 16 eligible studies conducted on 121 trial sites with more than 9,500 cows available to assess the impact of monensin on health and reproductive outcomes. Table 2 is a summary of all meta-analysis findings for each outcome from the studies and trials presented in Table 1. Over all the trials analyzed, monensin decreased the risk of ketosis $[\mathrm{RR}=0.75,95 \%$ confidence intervals $(\mathbf{C I})=0.63$ to $0.89 ; P=0.001)$, DA $(\mathrm{RR}=0.75,95 \% \mathrm{CI}=0.61$ to $0.93 ; P=0.008)$, and mastitis $(\mathrm{RR}=0.91,95 \% \mathrm{CI}=0.83$ to $0.98 ; P=0.016$; Table 2). No significant effects of monensin were found for 
Table 2. Summary of risk ratio estimates of monensin on health and reproduction in lactating dairy cows derived from meta-analysis ${ }^{1}$

\begin{tabular}{|c|c|c|c|c|c|c|c|c|c|c|}
\hline \multirow[b]{3}{*}{ Measured outcomes } & \multirow{3}{*}{$\begin{array}{c}\text { Trials, } \\
\mathrm{n}\end{array}$} & \multirow{3}{*}{$\begin{array}{c}\text { Trial } \\
\text { sites, } \\
\mathrm{n}\end{array}$} & \multicolumn{4}{|c|}{ Cows, $\mathrm{n}$} & \multirow[b]{3}{*}{$\mathrm{RR}^{2}$} & \multirow{3}{*}{$\begin{array}{l}\text { RR } 95 \% \\
\text { confidence } \\
\text { interval }\end{array}$} & \multirow[b]{3}{*}{$P$-value } & \multirow{3}{*}{$\begin{array}{c}I^{2} \\
\text { (95\% uncertainty } \\
\text { interval) }\end{array}$} \\
\hline & & & \multicolumn{2}{|c|}{ Treatment } & \multicolumn{2}{|c|}{ Control } & & & & \\
\hline & & & Unaffected & Affected & Unaffected & Affected & & & & \\
\hline Dystocia & 11 & 96 & 2,908 & 230 & 2,979 & 153 & 1.39 & $(0.92-2.11)$ & 0.118 & $71(46-84)$ \\
\hline Retained placenta & 19 & 101 & 3,682 & 478 & 3,725 & 474 & 1.01 & $(0.90-1.13)$ & 0.890 & $46(7-68)$ \\
\hline Milk fever & 17 & 100 & 3,224 & 196 & 3,244 & 178 & 1.11 & $(0.91-1.34)$ & 0.309 & $0(0-51)$ \\
\hline Metritis & 12 & 93 & 2,703 & 374 & 2,741 & 340 & 1.14 & $(0.91-1.42)$ & 0.243 & $51(6-75)$ \\
\hline Mastitis & 18 & 107 & 2,379 & 665 & 2,203 & 733 & 0.91 & $(0.83-0.98)$ & 0.016 & $0(0-49)$ \\
\hline Endometritis & 11 & 97 & 1,920 & 68 & 1,888 & 84 & 0.80 & $(0.59-1.08)$ & 0.140 & $0(0-60)$ \\
\hline Lameness & 10 & 104 & 2,319 & 493 & 2,232 & 458 & 1.00 & $(0.90-1.11)$ & 0.978 & $0(0-62)$ \\
\hline Culling & 8 & 92 & 2,243 & 432 & 2,140 & 444 & 0.96 & $(0.85-1.08)$ & 0.412 & $2(0-68)$ \\
\hline First-service conception risk & 20 & 73 & 2,392 & 1,630 & 2,304 & 1,669 & 0.97 & $(0.92-1.02)$ & 0.283 & $18(0-52)$ \\
\hline
\end{tabular}

${ }^{1}$ All trials analyzed are from those reported in Table 1.

${ }^{2} \mathrm{RR}=$ relative risk.

milk fever $(\mathrm{RR}=1.11,95 \% \mathrm{CI}=0.91$ to $1.34 ; P=0.309)$, lameness $(\mathrm{RR}=1.00,95 \% \mathrm{CI}=0.90$ to $1.11 ; P=0.978)$, dystocia $(\mathrm{RR}=1.39,95 \% \mathrm{CI}=0.92$ to $2.11 ; P=0.118)$, $\mathrm{RP}(\mathrm{RR}=1.01,95 \% \mathrm{CI}=0.90$ to $1.13 ; P=0.890)$ or metritis $(\mathrm{RR}=1.10,95 \% \mathrm{CI}=0.97$ to $1.26 ; P=0.144$; Table 2). However, there was evidence of heterogeneity on the impact of monensin on dystocia $\left(\chi^{2}=34.71, \mathrm{df}=\right.$ $10 ; P=0.0001), \mathrm{RP}\left(\chi^{2}=33.24, \mathrm{df}=18 ; P=0.016\right)$, and metritis $\left(\chi^{2}=22.56, \mathrm{df}=11 ; P=0.02\right)$; therefore, a random effect model was used and sources of heterogeneity were explored with meta-regression. Monensin had no effect on FSCR $(\mathrm{RR}=0.97,95 \% \mathrm{CI}=0.92$ to $1.02 ; P=0.283$ ).

Forest plots illustrating the impact of monensin on DA, ketosis, and mastitis are presented in Figures 1 to 3 , respectively. There was no evidence of heterogeneity of response or publication bias for these outcomes. Forest plots for dystocia, RP, and metritis are presented in Figures 4 to 6, respectively. All of these models displayed moderate heterogeneity and random effects models were subsequently used.

There was no evidence of publication bias for any of the health or reproductive outcomes. Assessment of the effect of influential studies revealed a large impact of one study on dystocia (Melendez et al., 2006a), but no large effects for other outcomes. The study of Melendez et al. (2006a) had a greater impact on increasing the risk of dystocia than other studies and this was considered in the subsequent meta-regression models. Metaregression analysis was conducted only for those outcomes where monensin showed significant heterogeneity of response (dystocia, RP, and metritis). In these analyses, only method of delivery of monensin and time of precalving treatment start relative to calving were significant variables. Dose of monensin was not signifi- cant. A summary of the results for meta-regression findings for dystocia, RP, and metritis are summarized in Table 3. For these coefficients, a negative value indicates that the variable contributes to reducing the $R R$ value for monensin (decreasing disease risk), whereas a positive coefficient indicates an increase in the $R R$ response with monensin (increasing disease risk). For example, the variable described as treated within $21 \mathrm{~d}$ of calving was significant in the models of dystocia and RP. A negative coefficient means that cows treated with monensin within this time frame had a reduced risk of dystocia and RP compared with cows treated with monensin for longer than this time frame before calving.

For further investigation of the effect of monensin on risk of metritis, the meta-analysis was stratified by CRC use vs. in-feed delivery. The risk of metritis was reduced when monensin was used in the form of a CRC, (RR $=0.83, P=0.04)$, whereas the in-feed analysis resulted in an increase in the risk of metritis $(\mathrm{RR}=$ $1.42, P<0.001)$.

The data that was pooled to assess the duration from calving to pregnancy met the criteria for survival analysis. Survival analysis of 4,100 cows from 6 studies showed that there was no significant effect of monensin on pregnancy rate in lactating dairy cows (hazards ratio $=0.93,95 \% \mathrm{CI}=0.83$ to $1.05 ; P=0.244)$. The forest plot for FSCR is presented in Figure 7.

\section{DISCUSSION}

Investigations of metabolic diseases are hindered by the relative infrequency of some of these conditions. Large numbers of cattle are required to effectively test hypotheses relating to means of controlling these condi- 


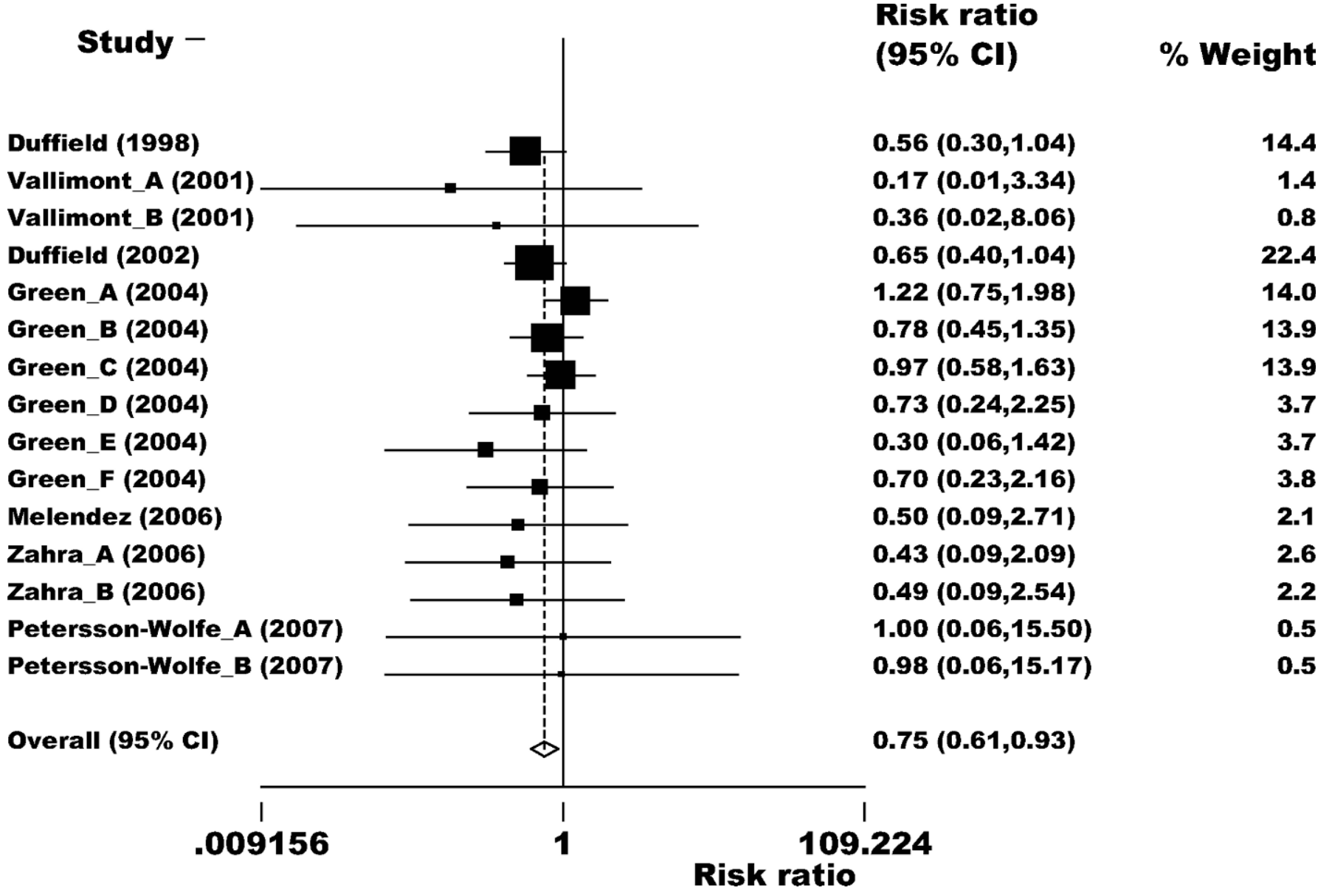

Figure 1. Forest plot of the effect of monensin on displaced abomasum in lactating dairy cows. Study refers to the first author and year of the publication; an underscore after the first author's name followed by a letter designates a trial for that study. Vallimont: $\mathrm{A}=$ monensin vs. control; $\mathrm{B}=$ monensin + rBST vs. rBST; Green: $\mathrm{A}=$ monensin $(8 \mathrm{ppm})$ vs. control, 1st lactation of study; $\mathrm{B}=\mathrm{monensin}(16 \mathrm{ppm})$ vs. control, 1st lactation of study; $\mathrm{C}=$ monensin $(24 \mathrm{ppm})$ vs. control, 1st lactation of study; $\mathrm{D}=$ monensin $(8 \mathrm{ppm})$ vs. control, $2 \mathrm{nd}$ lactation of study; $\mathrm{E}=$ monensin $(16 \mathrm{ppm})$ vs. control, 2nd lactation of study; $\mathrm{F}=$ monensin $(24 \mathrm{ppm})$ vs. control, 2nd lactation of study; Zahra: A = monensin controlled release capsule $(\mathrm{CRC})$ vs. control; B = monensin CRC + rumen-protected choline (RPC) vs. RPC; Petersson-Wolfe: A = monensin $(22 \mathrm{ppm})$ vs. control; B = monensin CRC vs. control. Risk ratio is the same as relative risk. A risk ratio of 1 indicates no effect of treatment (indicated by the solid vertical line); points to the left of the line represent a reduction in the parameter, and points to the right of the line indicate an increase. Each square represents the mean risk ratio for that study. The upper and lower limit of the line connected to the square represents the upper and lower 95\% confidence interval for the risk ratio. The size of the square reflects the relative weighting of the study to the overall effect size estimate with larger squares representing greater weight. The dotted vertical line represents the overall effect size estimate or the risk ratio. The diamond at the bottom represents the $95 \%$ confidence interval for the overall estimated risk ratio.

tions. The database created following collation of eligible studies in this meta-analysis provided adequate statistical power to investigate the effect of monensin on disease and reproduction.

A reduction in both the risk of DA and clinical ketosis were consistent across most studies included in this meta-analysis. These findings have been previously reported in a summary of 2 studies (Duffield et al., 2002). A reduction in circulating ketone and NEFA concentrations and a concomitant increase in glucose (Duffield et al., 2008a) are strong positive indicators of improved energy balance with monensin in the transition period that might help explain the reduction in the occurrence of both diseases. Subclinical ketosis has been reported to be a risk factor for clinical ketosis (Dohoo and Martin, 1984). If clinical ketosis was merely an extension of subclinical ketosis, one would assume that the monensin effect would be similar in magnitude for both clinical and subclinical ketosis. The current meta-analysis showed that with monensin treatment, there was a $25 \%$ reduction in the risk of clinical ketosis $(R R=0.75)$. However, a 50\% decrease in the incidence of subclinical ketosis was reported in one large field study across 3 thresholds of serum BHBA (Duffield et al., 1998). Risk 


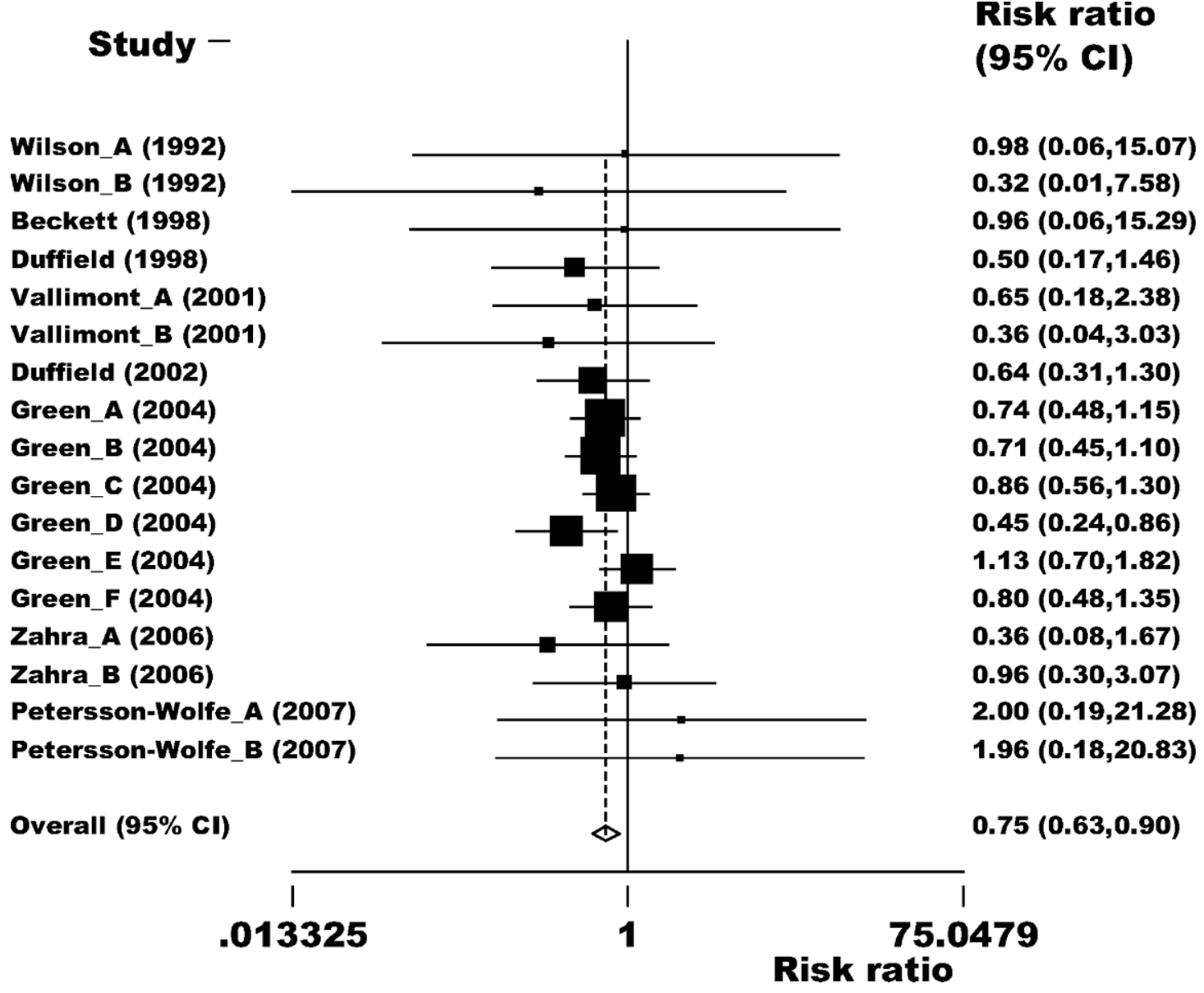

Figure 2. Forest plot of the effect of monensin on ketosis in lactating dairy cows. Study refers to the first author and year of the publication; an underscore after the first author's name followed by a letter designates a trial for that study. Wilson: A = monensin vs. control started precalving; $\mathrm{B}=$ monensin vs. control started after calving; Vallimont: $\mathrm{A}=$ monensin vs. control; $\mathrm{B}=\mathrm{monensin}+\mathrm{rBST}$ vs. rBST; Green: A = monensin ( $8 \mathrm{ppm})$ vs. control, 1st lactation of study; B = monensin (16 ppm) vs. control, 1st lactation of study; C = monensin $(24 \mathrm{ppm})$ vs. control, 1st lactation of study; $\mathrm{D}=$ monensin $(8 \mathrm{ppm})$ vs. control, 2nd lactation of study; $\mathrm{E}=$ monensin $(16 \mathrm{ppm})$ vs. control, 2nd lactation of study; F = monensin (24 ppm) vs. control, 2nd lactation of study; Zahra: A = monensin controlled release capsule (CRC) vs. control; $\mathrm{B}=$ monensin $\mathrm{CRC}+$ rumen-protected choline $(\mathrm{RPC})$ vs. $\mathrm{RPC}$; Petersson-Wolfe: $\mathrm{A}=$ monensin $(22 \mathrm{ppm}) \mathrm{vs}$. control; $\mathrm{B}=$ monensin $\mathrm{CRC}$ vs. control. Risk ratio is the same as relative risk. A risk ratio of 1 indicates no effect of treatment (indicated by the solid vertical line); points to the left of the line represent a reduction in the parameter, and points to the right of the line indicate an increase. Each square represents the mean risk ratio for that study. The upper and lower limit of the line connected to the square represents the upper and lower 95\% confidence interval for the risk ratio. The size of the square reflects the relative weighting of the study to the overall effect size estimate with larger squares representing greater weight. The dotted vertical line represents the overall effect size estimate or the risk ratio. The diamond at the bottom represents the $95 \%$ confidence interval for the overall estimated risk ratio.

of clinical ketosis is influenced by factors apart from homeostatic energy metabolism, including parity, BCS, and other periparturient disease conditions. Lean et al. (1994b) found that cows with clinical ketosis were characterized by significantly lower DMI had greater risk of prior illness, suggesting that clinical ketosis is not merely an extension of the subclinical condition. Alternately, or concurrently, an inability to account for confounders in this meta-analysis may also explain a reduced magnitude of effect for clinical ketosis compared with subclinical ketosis. A lack of a standardized disease definition is a problem in the literature for keto- sis and other peripartum diseases (Lean et al., 1994b; Kelton et al., 1998). Differences in diagnosis and definition among studies could bias the estimated risk ratios toward the null.

Both elevated serum concentrations of NEFA and BHBA have been identified as a priori risk factors for the occurrence of DA (Geishauser et al., 1997; Cameron et al., 1998; LeBlanc et al., 2005). Monensin treatment reduces plasma NEFA and BHBA in periparturient cows and these actions appear to be associated with the reduction in DA. However, the underlying mechanism for this reduction is unclear. It is possible that the im- 


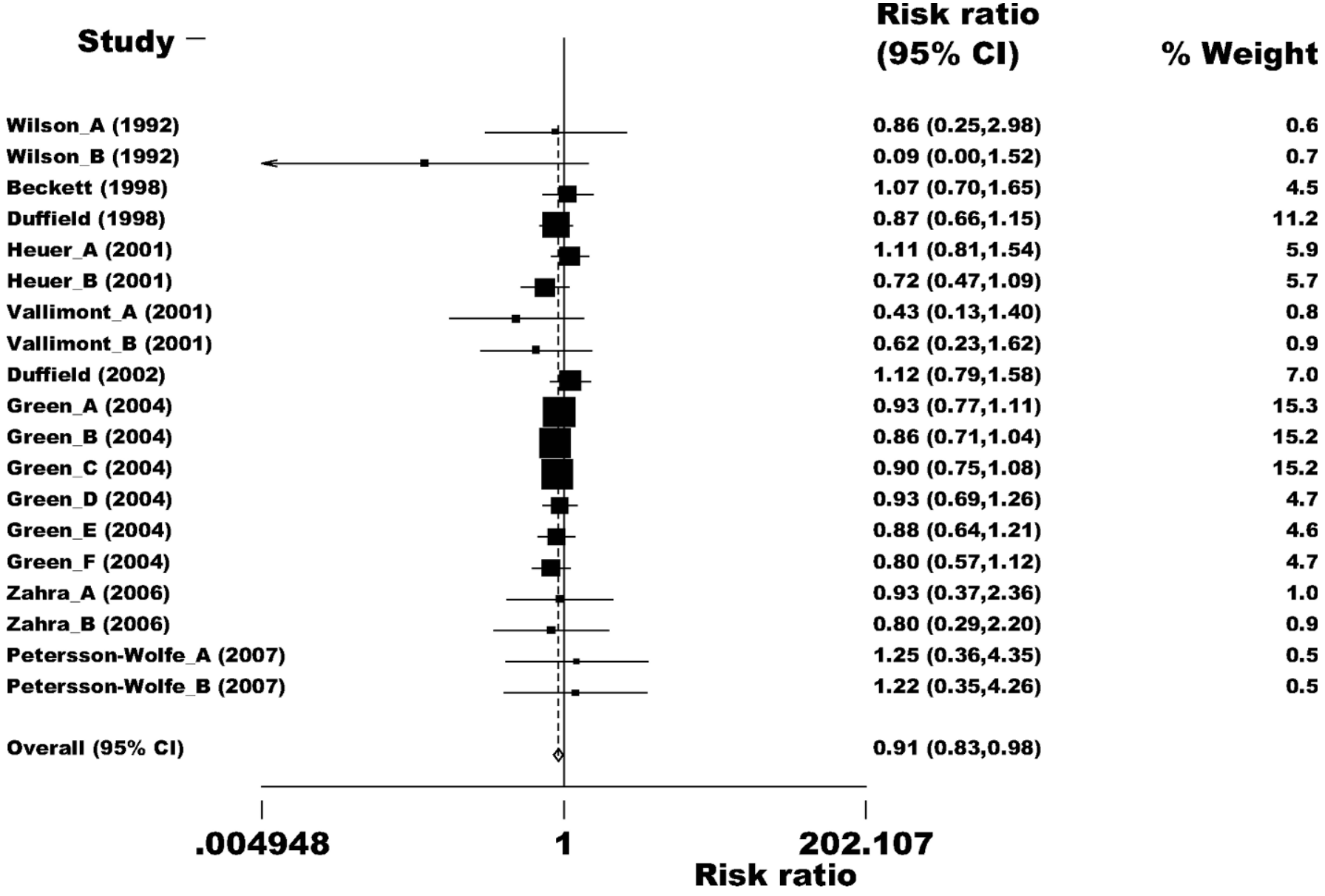

Figure 3. Forest plot of the effect of monensin on mastitis in lactating dairy cows. Study refers to the first author and year of the publication; an underscore after the first author's name followed by a letter designates a trial for that study. Wilson: A = monensin vs. control started precalving; $\mathrm{B}=$ monensin vs. control started after calving; Vallimont: $\mathrm{A}=$ monensin vs. control; $\mathrm{B}=$ monensin $+\mathrm{rBST}$ vs. rBST; Heuer: $\mathrm{A}=$ monensin vs. control commenced precalving; $\mathrm{B}=$ monensin vs. control commenced postcalving; Green: $\mathrm{A}=$ monensin $(8$ ppm) vs. control, 1st lactation of study; $\mathrm{B}=$ monensin $(16 \mathrm{ppm})$ vs. control, 1st lactation of study; $\mathrm{C}=$ monensin $(24 \mathrm{ppm})$ vs. control, 1 st lactation of study; $\mathrm{D}=$ monensin $(8 \mathrm{ppm})$ vs. control, 2 nd lactation of study; $\mathrm{E}=$ monensin $(16 \mathrm{ppm})$ vs. control, 2nd lactation of study; $\mathrm{F}=$ monensin $(24 \mathrm{ppm})$ vs. control, 2nd lactation of study; Zahra: A = monensin controlled release capsule (CRC) vs. control; B = monensin CRC + rumen-protected choline (RPC) vs. RPC; Petersson-Wolfe: A = monensin ( $22 \mathrm{ppm}$ ) vs. control; $\mathrm{B}=$ monensin CRC vs. control. Risk ratio is the same as relative risk. A risk ratio of 1 indicates no effect of treatment (indicated by the solid vertical line); points to the left of the line represent a reduction in the parameter, and points to the right of the line indicate an increase. Each square represents the mean risk ratio for that study. The upper and lower limit of the line connected to the square represents the upper and lower $95 \%$ confidence interval for the risk ratio. The size of the square reflects the relative weighting of the study to the overall effect size estimate with larger squares representing greater weight. The dotted vertical line represents the overall effect size estimate or the risk ratio. The diamond at the bottom represents the $95 \%$ confidence interval for the overall estimated risk ratio.

proved metabolic states and more stable rumen conditions may maintain a consistent DMI through transition, which results in a lower DA risk.

The impact of monensin on reducing mastitis by $9 \%$ is a small effect but an interesting finding. Reductions in mastitis incidence with monensin treatment (Heuer et al., 2001) and for lasalocid treatment (McDougall et al., 2004) have been previously reported. The mechanism for this is most likely to be an improvement in energy metabolism, improving immune function and allowing the cow to better mount a strong defense against infection challenge. Stephenson et al. (1997) suggest that the improvement in absorption of bivalent cations with monensin treatment could also influence responses to disease, because these cations are important in antioxidant and neutrophil and macrophage defense mechanisms. Monensin has been shown to improve neutrophil chemotaxis (Stephenson et al., 1996), and elevations in BHBA and NEFA concentrations have been associated with impaired immune function (Suriyasathaporn et al., 2000; Lacetera et al., 2004). If this is true, most of the effect would be expected in early 


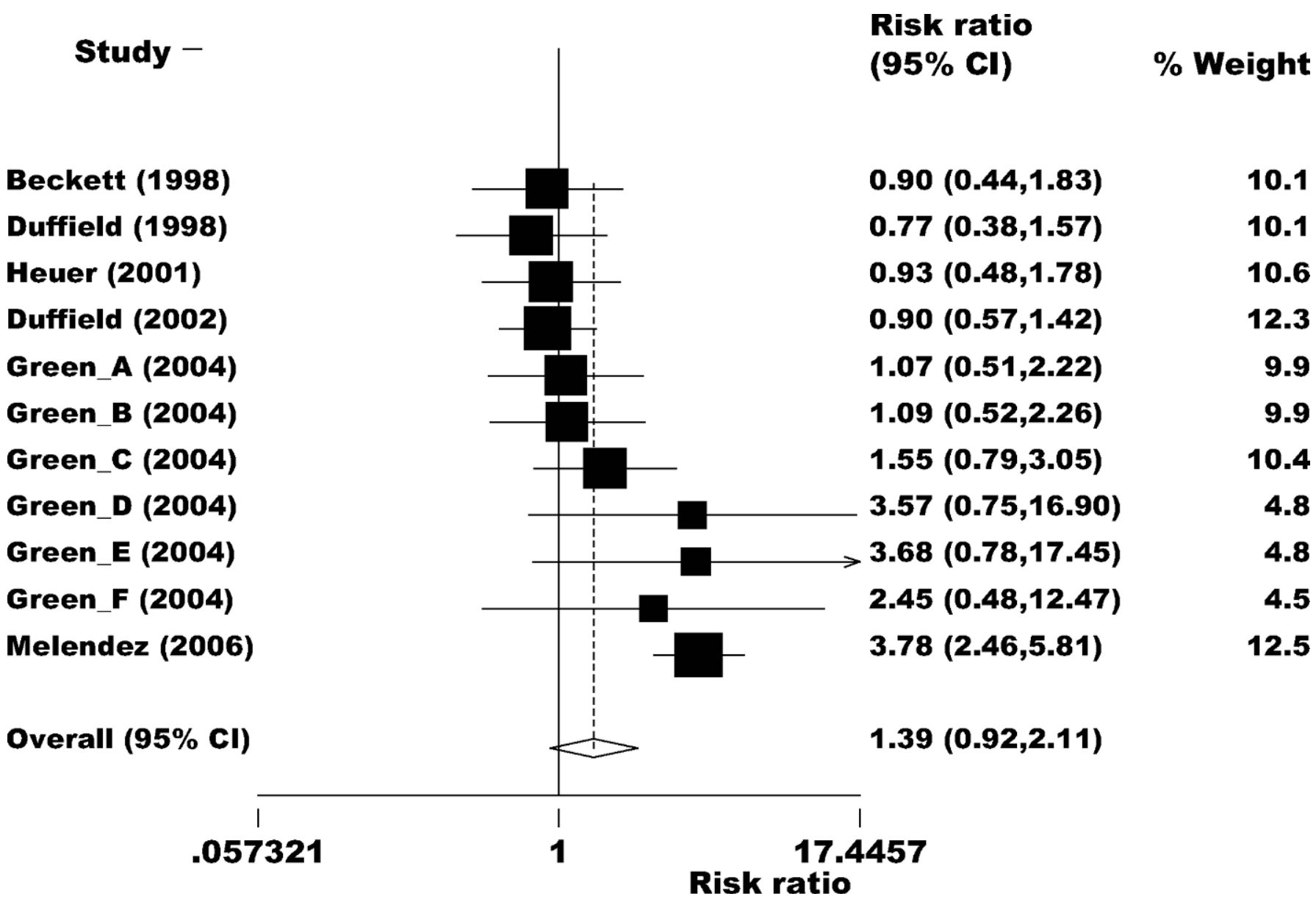

Figure 4. Forest plot of the effect of monensin on dystocia in lactating dairy cows. Study refers to the first author and year of the publication; an underscore after the first author's name followed by a letter designates a trial for that study. Green: $\mathrm{A}=$ monensin ( 8 ppm) vs. control, 1st lactation of study; B = monensin $(16 \mathrm{ppm})$ vs. control, 1st lactation of study; C = monensin (24 ppm) vs. control, 1st lactation of study; D = monensin (8 ppm) vs. control, 2nd lactation of study; $\mathrm{E}=$ monensin (16 ppm) vs. control, 2nd lactation of study; F = monensin $(24 \mathrm{ppm})$ vs. control, 2nd lactation of study. Risk ratio is the same as relative risk. A risk ratio of 1 indicates no effect of treatment (indicated by the solid vertical line); points to the left of the line represent a reduction in the parameter, and points to the right of the line indicate an increase. Each square represents the mean risk ratio for that study. The upper and lower limit of the line connected to the square represents the upper and lower $95 \%$ confidence interval for the risk ratio. The size of the square reflects the relative weighting of the study to the overall effect size estimate with larger squares representing greater weight. The dotted vertical line represents the overall effect size estimate or the risk ratio. The diamond at the bottom represents the $95 \%$ confidence interval for the overall estimated risk ratio.

lactation, because this is the risk period for elevated plasma NEFA and BHBA concentrations. With the exception of the studies by Green and Wilkinson (2004) and Heuer et al. (2001), all other studies ended in early (up to 100 DIM) or mid lactation (up to 160 DIM). It is estimated that nearly $50 \%$ of clinical mastitis occurs in the first $100 \mathrm{~d}$ of lactation (Hogan et al., 1989). Consequently, one may also expect an effect of monensin on severity or duration of mastitis; however, data on this was lacking for most trials. Further, analysis of SCC as an absolute value and as a change in value to estimate new infection rates would be useful data but these data were not reported for these studies.

The impacts of monensin on dystocia, $\mathrm{RP}$, and metritis were unexpected. All 3 outcomes had moderate het- erogeneity of response, required a random effects model, and were subjected to meta-regression. Explanatory variables for these disease outcomes were days before calving for treatment start and treatment delivery using the CRC device. For dystocia, days before calving at which treatment commenced was significant as a linear effect. This effect was also dichotomized at $\leq 21$ or $>21 \mathrm{~d}$ before calving to distinguish a close-up and a far-off dry period. Within studies that treated cows with monensin for more than $21 \mathrm{~d}$ before calving, there was an increased risk of dystocia. One study in this analysis (Melendez et al., 2006a) was an influential outlier and increased the point estimate of dystocia with monensin treatment. However, meta-regression with these data excluded found that days before calving for 


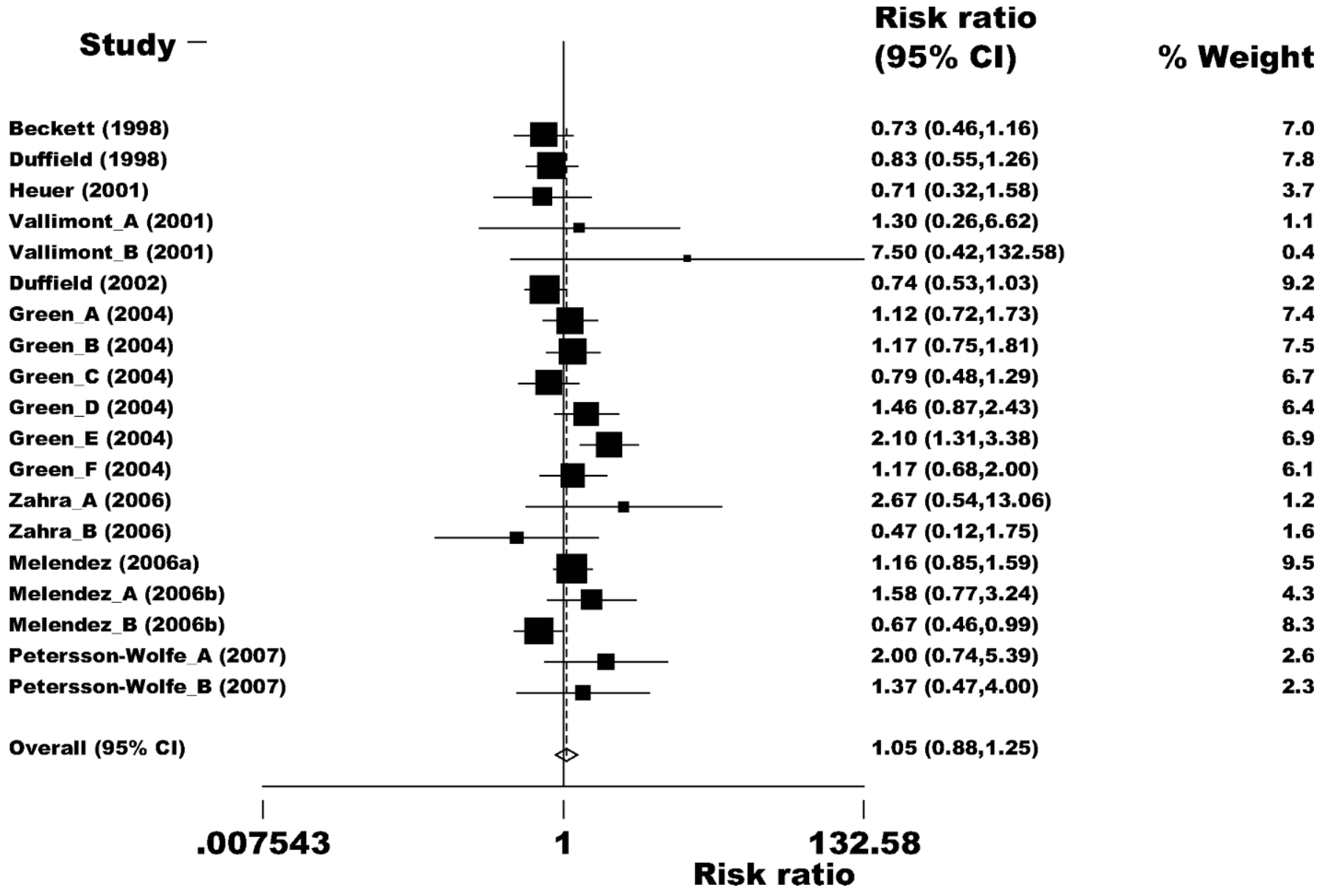

Figure 5. Forest plot of the effect of monensin on retained placenta in lactating dairy cows. Study refers to the first author and year of the publication; an underscore after the first author's name followed by a letter designates a trial for that study. Vallimont: A = monensin vs. control; $\mathrm{B}=$ monensin + rBST vs. rBST; Green: $\mathrm{A}=$ monensin $(8 \mathrm{ppm})$ vs. control, 1st lactation of study; $\mathrm{B}=$ monensin $(16 \mathrm{ppm})$ vs. control, 1st lactation of study; C = monensin $(24 \mathrm{ppm})$ vs. control, 1st lactation of study; D = monensin (8 ppm) vs. control, 2nd lactation of study; $\mathrm{E}=$ monensin $(16 \mathrm{ppm})$ vs. control, 2nd lactation of study; $\mathrm{F}=$ monensin $(24 \mathrm{ppm})$ vs. control, 2nd lactation of study; Zahra: A = monensin controlled release capsule (CRC) vs. control, B = monensin CRC + rumen-protected choline (RPC) vs. RPC; Melendez (2006b): $\mathrm{A}=$ monensin $\mathrm{CRC}$ vs. control, primiparous; $\mathrm{B}=$ monensin $\mathrm{CRC}$ vs. control, multiparous; Petersson-Wolfe: $\mathrm{A}=$ monensin $(22$ ppm) vs. control; $\mathrm{B}=$ monensin $\mathrm{CRC}$ vs. control. Risk ratio is the same as relative risk. A risk ratio of 1 indicates no effect of treatment (indicated by the solid vertical line); points to the left of the line represent a reduction in the parameter, and points to the right of the line indicate an increase. Each square represents the mean risk ratio for that study. The upper and lower limit of the line connected to the square represents the upper and lower 95\% confidence interval for the risk ratio. The size of the square reflects the relative weighting of the study to the overall effect size estimate with larger squares representing greater weight. The dotted vertical line represents the overall effect size estimate or the risk ratio. The diamond at the bottom represents the $95 \%$ confidence interval for the overall estimated risk ratio.

treatment was significant. Findings of increased dystocia risk in the trials of Green and Wilkinson (2004), in particular, were consistent with those of Melendez et al. (2006a). This suggests that an increased risk of dystocia with increased days of treatment with monensin before calving may be a real biologic effect rather than a spurious finding of one large study. Arias (1993) found that dairy calf birth weight was increased with monensin treatment. In that study, conducted on 5 farms, mean birth weight of calves from untreated heifers was $37.7 \mathrm{~kg}$ compared with $41.0 \mathrm{~kg}$ for calves from monensin-treated heifers. These findings may relate to the effect of monensin on glucose metabolism. A previous meta-analysis (Duffield et al., 2008a) reported that serum glucose was increased postcalving but not precalving with monensin. Stephenson et al. (1997) postulated that this effect may be because glucose was partitioned to the fetus. Prolonged partitioning of glucose to the fetus through the dry period may increase fetal size. However, it is possible that other effects of monensin, including effects on protein metabolism (Duffield et al., 2008a), may influence this response. Fetal growth is primarily controlled through placental growth, which is influenced by nutrition, stress, disease, genetics, and 


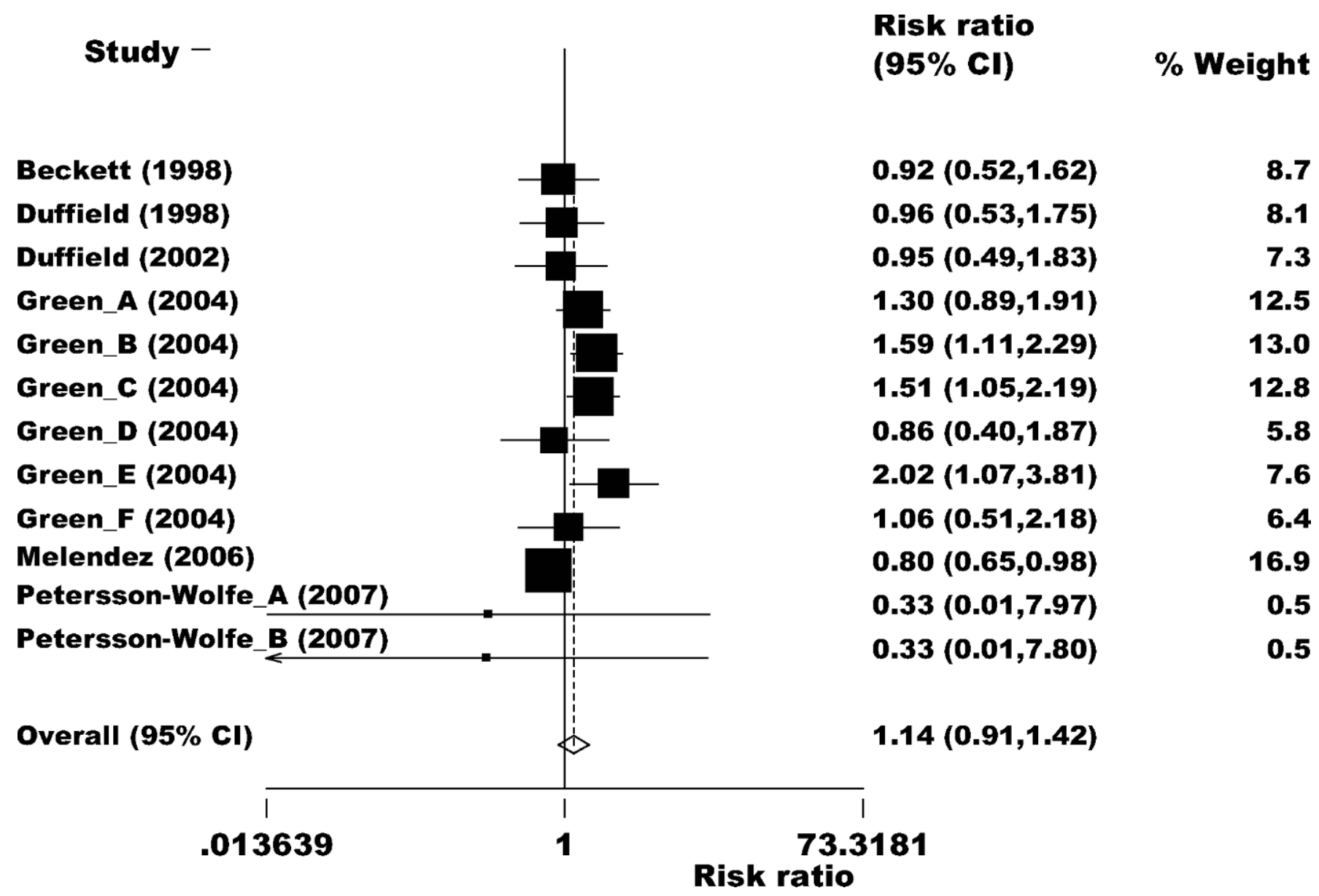

Figure 6. Forest plot of the effect of monensin on metritis in lactating dairy cows. Study refers to the first author and year of the publication; an underscore after the first author's name followed by a letter designates a trial for that study. Green: $\mathrm{A}=$ monensin (8 ppm) vs. control, 1st lactation of study; B = monensin $(16 \mathrm{ppm})$ vs. control, 1st lactation of study; $\mathrm{C}=$ monensin $(24 \mathrm{ppm})$ vs. control, 1 st lactation of study; D = monensin ( $8 \mathrm{ppm})$ vs. control, 2nd lactation of study; $\mathrm{E}=$ monensin (16 ppm) vs. control, 2nd lactation of study; F = monensin $(24 \mathrm{ppm})$ vs. control, 2nd lactation of study; Petersson-Wolfe: $\mathrm{A}=$ monensin $(22 \mathrm{ppm})$ vs. control; $\mathrm{B}=$ monensin controlled release capsule vs. control. Risk ratio is the same as relative risk. A risk ratio of 1 indicates no effect of treatment (indicated by the solid vertical line); points to the left of the line represent a reduction in the parameter, and points to the right of the line indicate an increase. Each square represents the mean risk ratio for that study. The upper and lower limit of the line connected to the square represents the upper and lower 95\% confidence interval for the risk ratio. The size of the square reflects the relative weighting of the study to the overall effect size estimate with larger squares representing greater weight. The dotted vertical line represents the overall effect size estimate or the risk ratio. The diamond at the bottom represents the $95 \%$ confidence interval for the overall estimated risk ratio.

maternal maturity (Wu et al., 2006). Glucose kinetics in the fetus and placenta of ruminants are complex and reflect glucose supply, glucose transporter proteins, and metabolism of amino acids to glucose by the fetus (Bell and Bauman, 1997). Increases in body weight of the dam with monensin through the dry period could increase internal fat deposition of the dam. An increase in fetal weight and a smaller effective pelvic diameter of the dam could increase the risk of dystocia. It is possible that both the energy density of the dry period diet and BCS of cows entering the dry period may influence this treatment response with monensin. However, there are simply too few studies currently to evaluate these potential interactions.
The effect of monensin treatment on RP and metritis appears to follow a similar pattern to the effect of monensin on dystocia. An argument could be made that these effects are time ordered; that is, prolonged dry period exposure to monensin may have increased the risk of dystocia, leading to increased risk of retained placenta and subsequently metritis. However, days treated with monensin before calving was only significant for effects on risk of dystocia and RP. It is unclear how the use of the CRC improves the effect of monensin on metritis and RP compared with treatment delivery in a TMR. Analysis stratified by CRC use shows that the RR point estimates are $<1$ for both outcomes (RP data not presented), and statistically significant $(P=$ 
Table 3. Summary of significant meta-regression variables [(using $\log (R R)$ and $\log \operatorname{se}(R R)]$ influencing the effect of monensin on dystocia, retained placenta, and metritis

\begin{tabular}{|c|c|c|c|}
\hline Disease & Factor & $\begin{array}{l}\text { Coefficient } \\
(95 \% \text { CI })\end{array}$ & $P$-value \\
\hline \multicolumn{4}{|l|}{ Dystocia } \\
\hline & Intercept & $\begin{array}{l}0.877 \\
(0.381,1.373)\end{array}$ & 0.001 \\
\hline & $\begin{array}{l}\text { Treated within } 21 \mathrm{~d} \text { of calving } \\
\text { (compared with treatment beyond } 21 \mathrm{~d} \text { from calving) }\end{array}$ & $-0.877-0.248)$ & 0.006 \\
\hline \multirow{3}{*}{ Retained placenta } & Intercept & 0.364 & 0.006 \\
\hline & $\begin{array}{l}\text { Treated within } 21 \mathrm{~d} \text { of calving } \\
\text { (compared with treatment beyond } 21 \mathrm{~d} \text { from calving) }\end{array}$ & $\begin{array}{l}-0.261 \\
(-0.538,0.0158)\end{array}$ & 0.065 \\
\hline & $\begin{array}{l}\text { Controlled release capsule (CRC) } \\
\text { (compared with either topdress or TMR delivery) }\end{array}$ & 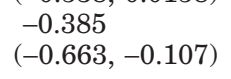 & 0.007 \\
\hline \multirow{2}{*}{ Metritis } & Intercept & $\begin{array}{l}0.352 \\
(0.163,0.541)\end{array}$ & 0.0001 \\
\hline & $\begin{array}{l}\text { CRC } \\
\text { (compared with either topdress or TMR delivery) }\end{array}$ & $\begin{array}{l}-0.538 \\
(-0.798,-0.228)\end{array}$ & 0.0001 \\
\hline
\end{tabular}

0.04 ) for reducing metritis, indicating a $16 \%$ reduction in risk of this condition over controls. This stratified analysis primarily separated out one large feed-delivery study (Green and Wilkinson, 2004) and it is possible that differences in observation intensity and disease definition for that series of trials might explain the results. However, it is worth considering the possibility of differences in delivery mechanism. The CRC delivers a consistent dose of monensin to the rumen, whereas the daily dose ingested in the TMR will depend on feed intake, and delivery of monensin in a topdress would provide a "spike" of monensin at each feeding. In the meta-analysis (Duffield et al., 2008a) examining metabolic effects of monensin, the CRC and topdress delivery methods provided smaller but more consistent effects on serum BHBA than did a TMR delivery. Further, topdress use enhanced glucose responses compared with either CRC or TMR delivery. There are no topdress studies represented in this analysis on metritis. However, the study by Heuer et al. (2001), using topdress treatment, reported a significant reduction in the incidence of endometritis with monensin, which included metritis as part of the disease definition.

Results obtained with the CRC studies suggest a potential for reductions in both $\mathrm{RP}$ and metritis incidence with monensin treatment. This effect may be mediated by indirect improvement of immune function through improved energy balance and, possibly, by improvements in absorption of bivalent cations that are vital in antioxidant and neutrophil and macrophage killing systems (Stephenson et al., 1996). However, the data for monensin on metritis and RP is influenced by both delivery method and days of treatment before calving. Further, like ketosis, both conditions lack standardized detection methods and disease definitions across stud- ies that could result in under- or over-reporting and in misclassification of disease. These factors could contribute to the heterogeneity of response found for metritis.

No effect for MF was anticipated and previous metaanalysis revealed no effect for monensin on serum calcium (Duffield et al., 2008a). Previous studies showing the capacity for monensin treatment to alter rumen fermentation patterns and reduced fluctuations in feed intake under rumen acid challenge suggested a potential for monensin to reduce lameness incidence (Burrin and Britton, 1986; Mutsvangwa et al., 2002). However, it was not possible to examine lameness specifically associated with laminitis. The impact of monensin on lameness was not significant, however, this area is worthy of further study.

Despite the improvements in health observed in the current meta-analysis and in several production measures (Duffield et al., 2008b) with monensin treatment, the risk of culling from the herd remained unchanged.

Analysis of clinical health events requires a considerable sample size to evaluate statistical significance because of the relatively rare occurrence for many diseases. For example, the power to determine a difference of $10 \%$ in mastitis incidence with a control incidence of $25 \%$ would be 0.79 with a $\alpha=0.05$ using 9,000 cows. Despite the power contained in the current study, considerably more data would have been available had more studies reported health events. Although small studies will be unlikely to identify clinical health benefits for specific treatments, authors should be encouraged to publish clinical health outcomes so that metaanalytic methods can be applied in the future to more effectively determine the impact of treatment and, just as importantly, sources of variation in treatment effects. 


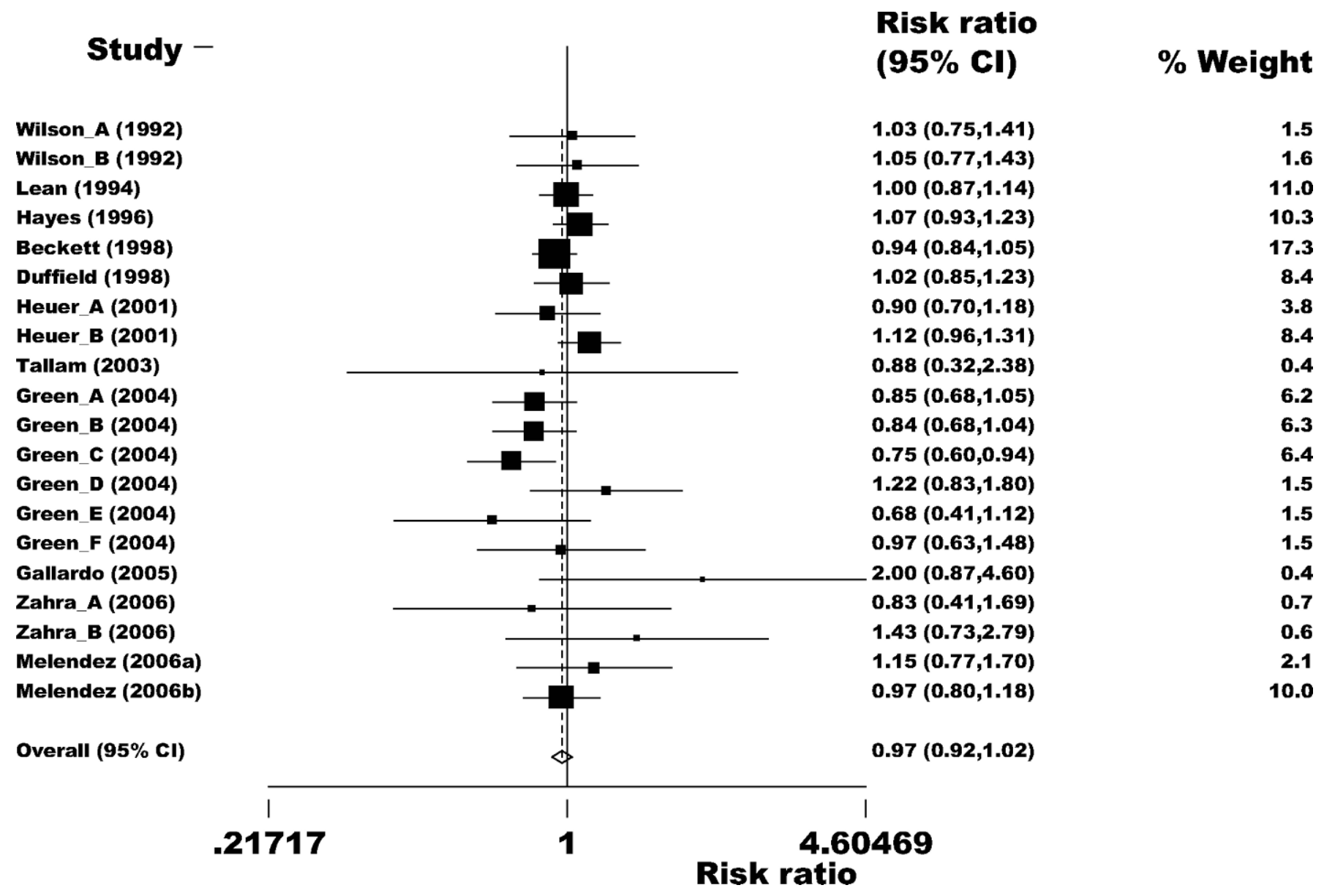

Figure 7. Forest plot of the effect of monensin on first-service conception risk in lactating dairy cows. Study refers to the first author and year of the publication; an underscore after the first author's name followed by a letter designates a trial for that study. Wilson: A = monensin vs. control started precalving; $\mathrm{B}=$ monensin vs. control started after calving; Heuer: $\mathrm{A}=$ monensin vs. control commenced precalving; $\mathrm{B}=$ monensin vs. control commenced postcalving; Green: $\mathrm{A}=$ monensin $(8 \mathrm{ppm})$ vs. control, 1st lactation of study; $\mathrm{B}=$ monensin $(16 \mathrm{ppm})$ vs. control, 1st lactation of study; $\mathrm{C}=$ monensin $(24 \mathrm{ppm})$ vs. control, 1st lactation of study; $\mathrm{D}=$ monensin $(8 \mathrm{ppm})$ vs. control, 2nd lactation of study; $\mathrm{E}=$ monensin $(16 \mathrm{ppm})$ vs. control, 2nd lactation of study; $\mathrm{F}=$ monensin (24 ppm) vs. control, 2nd lactation of study; Zahra: A = monensin controlled release capsule $(\mathrm{CRC})$ vs. control; $\mathrm{B}=$ monensin CRC + rumen-protected choline (RPC) vs. RPC. Risk ratio is the same as relative risk. A risk ratio of 1 indicates no effect of treatment (indicated by the solid vertical line); points to the left of the line represent a reduction in the parameter, and points to the right of the line indicate an increase. Each square represents the mean risk ratio for that study. The upper and lower limit of the line connected to the square represents the upper and lower 95\% confidence interval for the risk ratio. The size of the square reflects the relative weighting of the study to the overall effect size estimate with larger squares representing greater weight. The dotted vertical line represents the overall effect size estimate or the risk ratio. The diamond at the bottom represents the $95 \%$ confidence interval for the overall estimated risk ratio.

The lack of an effect on either FSCR or time to pregnancy is not surprising, given the number of large studies conducted that have previously reported no effect. It is particularly difficult to influence or explain variation in FSCR. Both tightly controlled (Westwood et al., 2002) and very large field studies (Curtis, 1997; Moss, 2001) have explained only approximately $7 \%$ of variance in FSCR in Australian dairy herds. However, more of the variance for the variable time to pregnancy was explained by the studies of Curtis (1997) and Westwood et al. (2002). In these studies, time to pregnancy was influenced by body weight change, milk production, and protein composition of the diet. The lack of a positive effect for monensin is somewhat puzzling given the improvement in glucose flux with monensin and positive effects of monensin on time to breeding reported in beef heifers (Bagley, 1993). However, it should be noted that this meta-analysis showed that reproductive performance was maintained and health improved with monensin use, while production increased (Duffield et al., $2008 \mathrm{~b})$. It is difficult to determine the effects of monensin treatment on nutrient balance, given that monensin improves efficiency of production (Duffield et al., 2008b). Consequently, energy, protein, mineral, and vi- 
tamin balances may not necessarily be positive with treatment. The lack of reproductive response to treatment provides an intriguing area for future research.

\section{CONCLUSIONS}

Monensin use during the transition period improves cow health by decreasing the risk of ketosis, DA, and mastitis. However, the effect of monensin on dystocia, $\mathrm{RP}$, and metritis is influenced by delivery method and duration of exposure to monensin in the dry period. Increasing duration of exposure of monensin in the dry period increased the risk of $\mathrm{RP}$ and dystocia. The use of the CRC reduced risk of $\mathrm{RP}$ and metritis. There was no significant effect of monensin identified for other health outcomes, risk of culling, and reproductive performance. These improvements in cow health were achieved while milk production is improved and DMI is reduced (Duffield et al., 2008b).

\section{ACKNOWLEDGMENTS}

We wish to acknowledge Valetta Taylor-Craig (technical assistant, Strategic Bovine Services) for her assistance with the literature search. We also wish to thank the various authors who provided additional data, in particular Cord Heuer (Massey University, New Zealand) who provided raw reproductive data for the pooled analysis. We also extend thanks to Elanco Animal Health (Guelph, ON, Canada; Macquarie Park, NSW, Australia; and Greenfield, IN) for generous funding support for this project.

\section{REFERENCES}

Abe, N., I. J. Lean, A. R. Rabiee, J. Porter, and C. Graham. 1994. Effects of sodium monensin on reproductive performance of dairy cattle. II. Effects on metabolites in plasma, resumption of ovarian cyclicity and oestrus in lactating cows. Aust. Vet. J. 71:277-282.

Arias, G. A. 1993. Effects of monensin delivered by a slow release device on aspects of performance in dairy heifers. M. Phil. Diss. Massey University, New Zealand.

Bagley, C. 1993. Nutritional management of replacement beef heifers: A review. J. Anim. Sci. 71:3155-3163.

Beckett, S., I. J. Lean, R. Dyson, W. Tranter, and L. Wade. 1998. Effects of monensin on the reproduction, health, and milk production of dairy cows. J. Dairy Sci. 81:1563-1573.

Begg, C., and M. Manumdar. 1994. Operating characteristics of a rank correlation test for publication bias. Biometrics 50:1088-1101.

Bell, A. W., and D. E. Bauman. 1997. Adaptations of glucose metabolism during pregnancy and lactation. J. Mamm. Biol. 2:265-278.

Bergen, W., and D. Bates. 1984. Ionophores: Their effect on production efficiency and mode of action. J. Anim. Sci. 58:1465-1483.

Bergstralh, E., J. Kosanke, and T. Therneau. 1993. SAS Macro PHLEV: Leverage residuals matrix for proportional hazard regression. Mayo Clinic Tech. Rep. 58.

Burrin, D., and R. Britton. 1986. Response to monensin in cattle during subacute acidosis. J. Anim. Sci. 63:888-893.

Cameron, R. E. B., P. B. Dyk, T. H. Herdt, J. B. Kaneene, R. Miller, H. F. Bucholtz, J. S. Liesman, M. J. Vandehaar, and R. S. Emery. 1998. Dry cow diet, management, and energy balance as risk factors for displaced abomasum in high producing dairy herds. J. Dairy Sci. 81:132-139.

Collett, D. 1994. Modelling Survival Data in Medical Research. Chapman and Hall, London, UK.

Curtis, M. 1997. Uterine infections in dairy cows. PhD Thesis. University of Sydney, Camden, NSW, Australia.

Dohoo, I., W. Martin, and H. Stryhn. 2003. Meta-analysis. Page 706 in Veterinary epidemiologic research. AVC Inc., Charlottetown, PEI, Canada.

Dohoo, I. R., and S. W. Martin. 1984. Subclinical ketosis: Prevalence and associations with production and disease. Can. J. Comp. Med. 48:1-5.

Duffield, T., R. Bagg, L. DesCoteaux, E. Bouchard, M. Brodeur, D. DuTremblay, G. Keefe, S. LeBlanc, and P. Dick. 2002. Prepartum monensin for the reduction of energy associated disease in postpartum dairy cows. J. Dairy Sci. 85:397-405.

Duffield, T. F., K. E. Leslie, D. Sandals, K. Lissemore, B. W. McBride, J. H. Lumsden, P. Dick, and R. Bagg. 1999. Effect of prepartum administration of a monensin controlled release capsule on cow health and reproduction. J. Dairy Sci. 82:2377-2384.

Duffield, T. F., A. R. Rabiee, and I. J. Lean. 2008a. A meta-analysis of the impact of monensin in lactating dairy cattle. Part 1 . Metabolic effects. J. Dairy Sci. 91:1334-1346.

Duffield, T. F., A. R. Rabiee, and I. J. Lean. 2008b. A meta-analysis of the impact of monensin in lactating dairy cattle. Part 2. Production effects. J. Dairy Sci. 91:1347-1360.

Duffield, T. F., D. Sandals, K. E. Leslie, K. Lissemore, B. W. McBride, J. H. Lumsden, P. Dick, and R. Bagg. 1998. Efficacy of monensin for the prevention of subclinical ketosis in lactating dairy cows. J. Dairy Sci. 81:2866-2873.

Egger, M., G. Davey Smith, and D. Altman, ed. 2001. Systematic reviews in health care: Meta-analysis in context. 2nd ed. BMJ Books, London, UK.

Egger, M., G. Davey Smith, M. Schneider, and C. Minder. 1997. Bias in meta-analysis detected by a simple, graphical test. Br. Med. J. 315:629-634.

Gallardo, M. R., A. R. Castillo, F. Bargo, A. A. Abdala, M. G. Maciel, H. Perez-Monti, H. C. Castro, and M. E. Castelli. 2005. Monensin for lactating dairy cows grazing mixed-alfalfa pasture and supplemented with partial mixed ration. J. Dairy Sci. 88:644-652.

Geishauser, T., K. Leslie, T. Duffield, and V. Edge. 1997. Evaluation of aspartate aminotransferase activity and $\beta$-hydroxybutyrate concentration in blood as tests for prediction of left displaced abomasum in dairy cows. Am. J. Vet. Res. 58:1216-1220.

Green, H., and J. Wilkinson. 2004. The effect of feeding monensin on lactation performance of dairy cows. Report to CVM. Elanco Animal Health, Greenfield, IN.

Hayes, D. P., D. U. Pfeiffer, and N. B. Williamson. 1996. Effect of intraruminal monensin capsules on reproductive performance and milk production of dairy cows fed pasture. J. Dairy Sci. 79:1000-1008.

Heuer, C., Y. H. Schukken, L. J. Jonker, J. I. D. Wilkinson, and J. P. T. M. Noorduizen. 2001. Effect of monensin on blood ketone bodies, incidence and recurrence of disease and fertility in dairy cows. J. Dairy Sci. 84:1085-1097.

Higgins, J., S. Thompson, J. Deeks, and D. Altman. 2003. Measuring inconsistency in meta-analyses. Br. Med. J. 327:557-560.

Hogan, J. S., K. L. Smith, K. H. Hoblet, P. S. Schoenberger, D. A. Todhunter, W. D. Hueston, D. E. Pritchard, G. L. Bowman, L. E. Heider, B. L. Brockett, and H. R. Conrad. 1989. Field survey of clinical mastitis in low somatic cell count herds. J. Dairy Sci. 72:1547-1556.

Kelton, D. F., K. D. Lissemore, and R. E. Martin. 1998. Recommendations for recording and calculating the incidence of selected clinical diseases of dairy cattle. J. Dairy Sci. 81:2502-2509.

Lacetera, N., D. Scalia, O. Franci, U. Bernabucci, B. Ronchi, and A. Nardone. 2004. Short communication: Effects of nonesterified fatty acids on lymphocyte function in dairy heifers. J. Dairy Sci. 87:1012-1014.

Lean, I. J., M. Bruss, H. Troutt, J. Galland, T. Farver, J. Rostami, C. Holmberg, and L. Weaver. 1994b. Bovine ketosis and somato- 
tropin: Risk factors for ketosis and effects of ketosis on health and production. Res. Vet. Sci. 57:200-209.

Lean, I. J., M. Curtis, R. Dyson, and B. Lowe. 1994a. Effects of sodium monensin on reproductive performance of dairy cattle. I. Effects on conception rates, calving-to-conception intervals, calving-toheat and milk production in dairy cows. Aust. Vet. J. 71:273-277.

Lean, I. J., and L. Wade. 1997. Effects of monensin on metabolism, production, and health of dairy cattle. Pages 50-70 in Usefulness of Ionophores in Lactating Dairy Cattle. K. Leslie, ed, University of Guelph, Guelph, Ontario, Canada.

LeBlanc, S. J., K. E. Leslie, and T. F. Duffield. 2005. Metabolic predictors of displaced abomasum in dairy cattle. J. Dairy Sci. 88:159-170.

Lowe, L., G. Ball, V. Carruthers, R. Dobos, G. Lynch, P. Moate, P. Poole, and S. Valentine. 1991. Monensin controlled-release intraruminal capsule for control of bloat in pastured dairy cows. Aust. Vet. J. 68:17-20.

McDougall, S., L. Young, and F. M. Anniss. 2004. Production and health of pasture-fed dairy cattle following oral treatment with the ionophore lasalocid. J. Dairy Sci. 87:2967-2976.

Melendez, P., J. P. Goff, C. A. Risco, L. F. Archbald, R. C. Littell, and G. A. Donovan. 2006a. Effect of administration of a controlledrelease monensin capsule on incidence of calving-related disorders, fertility, and milk yield in dairy cows. Am. J. Vet. Res. 673:537-543.

Melendez, P., G. Gonzalez, M. Benzaquen, C. Risco, and L. Archbald. $2006 \mathrm{~b}$. The effect of a monensin controlled-release capsule on the incidence of retained fetal membranes, milk yield and reproductive responses in Holstein cows. Theriogenology 662:234-241.

Moss, N. 2001. The epidemiology of subfertility in Australian dairy cows. PhD Thesis. University of Sydney, Camden, New South Wales, Australia.

Mutsvangwa, T., J. P. Walton, J. C. Plaizier, T. F. Duffield, R. Bagg, P. Dick, G. Vessie, and B. W. McBride. 2002. Effects of a monensin controlled-release capsule or premix on attenuation of subacute ruminal acidosis in dairy cows. J. Dairy Sci. 85:3454-3461.

Petersson-Wolfe, C. S., K. E. Leslie, T. Osborne, B. W. McBride, R. Bagg, G. Vessie, P. Dick, and T. F. Duffield. 2007. Effect of delivery method of monensin on dry matter intake, body condition score, and metabolic parameters in transition dairy cows. J. Dairy Sci. 90:1870-1879.

Russell, J. B., and H. J. Strobel. 1989. Effect of ionophores on ruminal fermentation. Appl. Environ. Microbiol. 55:1-6.

Stephenson, K. A., I. J. Lean, M. L. Hyde, M. A. Curtis, J. K. Garvin, and L. B. Lowe. 1997. Effects of monensin on the metabolism of periparturient dairy cows. J. Dairy Sci. 80:830-837.

Stephenson, K. A., I. J. Lean, and T. J. O'Meara. 1996. The effect of monensin on the chemotactic function of bovine neutrophils. Aust. Vet. J. 74:315-317.

Suriyasathaporn, W., C. Heuer, E. Noordhuizen-Stassen, and Y. Schukken. 2000. Hyperketonemia and udder defense: A review. Vet. Res. 31:397-412.

Tallam, S. K., T. F. Duffield, K. E. Leslie, R. Bagg, P. Dick, G. Vessie, and J. S. Walton. 2003. Ovarian follicular activity in lactating Holstein cows supplemented with monensin. J. Dairy Sci. 86:3498-3507.

Vallimont, J. E., G. A. Varga, A. Arieli, T. W. Cassidy, and K. A. Cummins. 2001. Effects of prepartum somatotropin and monensin on metabolism and production of periparturient Holstein dairy cows. J. Dairy Sci. 84:2607-2621.

Westwood, C. T., I. J. Lean, and J. K. Garvin. 2002. Factors influencing fertility of Holstein dairy cows: A multivariate description. J. Dairy Sci. 85:3225-3237.

Whitlock, R. H. 1969. Diseases of the abomasum associated with current feeding practices. J. Am. Vet. Med. Assoc. 154:1203.

Wilson, G. F., G. A. Lynch, and C. van der Wel. 1992. Effects of Rumensin anti-bloat capsules on plasma magnesium concentration and aspects of health and performance of pastured dairy cows. Massey University, Department of Animal Health, Palmerston North, New Zealand.

Wu, G., F. W. Bazer, J. M. Wallace, and T. E. Spencer, 2006. Boardinvited review: Intrauterine growth retardation: Implications for the animal sciences. J. Anim. Sci. 84:2316-2337.

Zahra, L. C., T. F. Duffield, K. E. Leslie, T. R. Overton, D. Putnam, and S. J. LeBlanc. 2006. Effects of rumen-protected choline and monensin on milk production and metabolism of periparturient dairy cows. J. Dairy Sci. 89:4808-4818. 